\title{
Cikkismertetés: Új lehetőségek a demencia megelőzésében
}

\author{
Article review: New possibilities in demencia prevention
}

\begin{abstract}
Ismertető: Mátyás Gabriellai,ii $\bowtie$
Ismertetett cikk: Livingston G, Huntley J, Sommerland A. Dementia prevention, intervention, and care: 2020 report of the Lancet Commission. Lancet. 2020 Aug 8;396(10248):413446. doi: 10.1016/S0140-6736(20)30367-6
\end{abstract}

$\begin{array}{ll}\text { Beküldve: } & \text { 2020. } 12.15 . \\ \text { Doi: } & 10.24365 / \text { ef.v62i1.675 }\end{array}$

Kulcsszavak: $\quad$ demencia; megelőzés; The Lancet-bizottság; megelőzhető kockázati tényező Keywords: $\quad$ dementia; prevention; The Lancet commission; modifiable risk factor

\section{HÁTTÉR}

Jelenleg mintegy 50 millióan szenvednek világszerte demenciában, vagyis olyan állapotban, amikor az idegsejtek pusztulása vagy működési zavara miatt szellemi képességeik hanyatlani kezdenek. A betegség évente körülbelül 1 billió amerikai dollár kiadást okoz. Ahogyan a 65 évesnél idősebbek aránya növekszik a népesség körében, párhuzamosan a demenciában szenvedők aránya is világszerte emelkedik. Az időskori demencia előfordulási aránya azonban egyes országokban annak ellenére is csökkent, hogy az idősek száma lakosságarányosan növekedett. E kedvező tendencia hátterében valószínűleg az oktatás, a táplálkozás, az egészségügyi ellátás, valamint életmódbeli változások állnak.

A The Lancet-bizottság (továbbiakban: Bizottság) 2017. évi jelentésében már azonosította a demencia 9 megelőzhető kockázati tényezőjét, melyek a következőek voltak: alacsony iskolai végzettség, magas vérnyomás, halláskárosodás, dohányzás, elhízás, depresszió, fizikai inaktivitás, cukorbetegség és kevés társas kapcsolat. A Bizottság ez évi jelentésében újabb meggyőző bizonyítékokra támaszkodva további 3 megelőzhető kockázati tényezőt azonosított: túlzott alkoholfogyasztás, traumás agysérülések és levegőszennyezés.

\section{ÚJ ISMERETEK}

A Bizottság az új kockázati tényezőkkel kiegészítve megalkotta a demenciamegelőzés 12 kockázati tényezős életpályamodelljét. A már előbb említett kockázati tényezők kivédésével a demens esetek mintegy 40 százalékát előzhetnénk meg világszerte. Mivel a demencia előfordulása magasabb az alacsony és közepes jövedelmű országokban, így itt arányaiban több demens eset válhat kivédhetővé. A Bizottság által megalkotott új modell, valamint a bizonyítékok szintézise világszerte kiemelkedő hatással lehet a szakpolitikai intézkedésekre.

\section{Prevenció}

Szakértők szerint a demencia prevenciója soha nem lehet túl korai vagy túl kései. A fiatalabb (45 éves alatti) korosztály esetében az alacsony iskolai végzettség negatívan hat a szellemi képességek tartalékaira, míg a középkorú (45-65 év közötti) és idősebb (65 évesnél idősebb) korosztály esetében a kockázati tényezők befolyásolják ezt a tartalékot és a neuropatológiai elváltozásokat. Az iskolázottság, a szegénység és az egészségegyenlőtlenségek mind a változás

\footnotetext{
' Debreceni Egyetem Általános Orvosi Kar, Népegészség- és Járványtani Intézet, Debrecen

ii Debreceni Egyetem Egészségtudományi Doktori Iskola, Debrecen
} 
kulcsfontosságú mozgatórugói. A leginkább rászoruló egyéneknek van a legnagyobb szükségük a változásra és ugyancsak ők azok, akiknek az esetében a legtöbb haszonnal járna. A szakpolitikai intézkedéseknek törekedniük kell arra, hogy minden gyermek részt vehessen a közoktatásban.

Azon népegészségügyi kezdeményezések, melyek csökkentik a fejsérüléseket és csökkentik a káros alkoholfogyasztást, egyaránt eredményesen csökkenthetik a fiatal- és időskori demenciát. Ugyancsak a demencia megelőzése, illetve későbbi megjelenése érdekében a középkorú korosztályba tartozó magas vérnyomásos betegek szisztolés vérnyomását úgy kell szabályozni, hogy az legfeljebb $130 \mathrm{Hgmm}$ legyen. A dohányzásról való leszokás sem lehet túl késői, ha a demencia megelőzéséről van szó, még későbbi életkorban is csökkenti a betegség kialakulásának kockázatát. Az aktív dohányzás mellett a passzív dohányzás is a demencia módositható kockázati tényezői között szerepel. Számos országban már korlátozták a másodlagos dohányfüst-expozíciót. A szakpolitikusoknak nyomást kell gyakorolniuk a kormányokra, hogy javítsák a légszennyezettségi mutatókat és törekedjenek a levegő minőségének javítása, ami ugyancsak fontos lenne a megelőzés szempontjából.

A Bizottság javasolja, hogy mind a középkorúak, mind az idősebb korosztályba tartozók is őrizzék meg fizikai, társadalmi és szellemi aktivitásukat, bár ezen tevékenységek protektív hatásáról jelenleg kevés bizonyíték áll rendelkezésünkre. A bizonyítékok alapján úgy tűnik, hogy halláskárosodás esetén a hallókészülék használata is csökkentheti a demencia kockázatát. A középkorú és idősebb korosztály esetében a rendszeres testmozgás is protektív hatással bírhat, ami valószínúleg az elhízás, a cukorbetegség és a kardiovaszkuláris kockázat csökkentésén keresztül hat. A depresszió a demencia rizikófaktora lehet, idősebb korban pedig a demencia depressziót okozhat. Ugyan a magatartásváltoztatás igen nehéz, a demencia kockázati tényező között nem mindig fedezhetünk fel ok-okozati viszonyt, egyéni szinten mégis nagy lehetőség nyílik csökkenteni a demencia kialakulásának kockázatát.

Az alacsony és közepes jövedelmű országokban nem mindenki számára hozzáférhető a középfokú oktatás, valamint a lakosság körében magas az elhízás, a magas vérnyomás és a halláskárosodás aránya. Mivel a cukorbetegségben szenve-dők aránya és a dohányzás gyakorisága is növekszik ezen országokban, így preventív beavatkozásokkal a demens esetek még nagyobb hányadát lehetne megakadályozni.

\section{Diagnózis}

A $\beta$-amiloid- és tau biomarkerek jelezhetik annak kockázatát, hogy az Alzheimer-kór demenciát okoz. Szellemileg ép egyéneknél ugyanakkor csak ezen biomarkerek megléte esetén a legtöbbször nem alakul ki demencia. Bár a pontos diagnózis a funkcionális problémákkal küzdő egyének és családjuk számára is fontos, jelenleg nincs arra bizonyíték, hogy a tünetek megjelenése előtt diagnosztizálni lehetne a betegséget.

A demencia kialakulásáról szóló ismereteink változnak az újabb kórokok feltárásával. Különösen a 90 év feletti korosztály esetében gyakori a kevert típusú demencia. A vérbiomarkerek elemzése hatékonyabb diagnosztikai módszernek túnik a demencia esetében, mint az agy-gerincvelő folyadék, illetve az agyi képalkotó markerek vizsgálata.

\section{Ellátás}

A demenciában szenvedők ellátásának egyik legfontosabb célkitǔzése a betegek jóllétének biztosítása. Esetükben általános, hogy több területet érintő problémákkal és tünetekkel küzdenek. Gondozásuk során a holisztikus beavatkozásokat kell előnyben részesíteni és a gondozásban részt vevő családtagokra is gondolni kell. Egyre több bizonyíték áll rendelkezésünkre a pszichoszociális intervenciók rövid távú hatékonyságáról, melyek a beteg igényeihez igazodva hatnak a neuropszichiátriai tünetekre. A bizonyítékokon alapuló intervenciók költséghatékonyan segítenek a gondozók szorongásos és depresszív tüneteinek csökkentésében.

A demenciában szenvedők testi egészségének megőrzése fontos szerepet játszik szellemi képességeik szinten tartásában. Általában több fizikai egészségproblémájuk van, mint az azonos korosztályba tartozóknak, de gyakran kevesebb közösségi egészségügyi ellátásban részesülnek, és számukra különösen nehéz az ellátáshoz való 
hozzáférés. A demenciában szenvedők gyakrabban szorulnak kórházi ellátásra, még az esetlegesen otthon kezelhető betegségek esetében is, mint a korosztályukba tartozó idős emberek. A Covid-19-járvány során is arányosan többen haláloztak el a demenciában szenvedők közül. A kórházi ápolás nem csak szorongást generál, de rossz kimeneteli eredményekkel jár és költségvonzata is magas. Az egészségügyi ellátásban tevékenykedő szakembereknek érdemes megfontolni a demencia lehetőségét azon demenciával nem diagnosztizált idős betegeknél, akik gyakrabban szorulnak kórházi ellátásra, illetve akiknél delírium alakul ki. A demenciában szenvedőknél gyakran alakul ki delírium, ami szintén szellemi hanyatláshoz vezet. A kórházi tartózkodás alatt megfelelő érzékszervi stimulációval, folyadékbevitel biztosításával és fertőzések megelőzésével csökkenthető a delírium kialakulásának kockázata.

A demencia megelőzésével és ellátásával kapcsolatos intézkedések jelentősen javíthatják nemcsak a demenciában szenvedők, hanem családjaik életminőségét és a társadalom egészére is pozitív hatással bírhatnak.

\section{ÖSSZEFOGLALÁS}

Tovább bővült a demencia megelőzhető kockázatainak köre: a demencia három új, módosítható kockázati tényezője a túlzott alkoholfogyasztás, a fejsérülések és a légszennyezés. A demencia már korábban azonosított, módosítható kockázati tényezői: az alacsony iskolai végzettség, magas vérnyomás, halláskárosodás, dohányzás, elhízás, depresszió, fizikai inaktivitás, cukorbetegség és a kevés társas kapcsolat. A 12 megelőzhető kockázati tényező a demenciák mintegy 40 százalékának kialakulásáért felel.

Az egészségegyenlőtlenségek által jobban sújtott etnikai kisebbségek, valamint a hátrányos helyzetű lakosság körében halmozottan fordulnak elő a demencia megelózhető kockázati tényezői. Ezeknek a kockázati tényezőknek a kezelése nem pusztán egészségfejlesztési feladat, hanem társadalmi beavatkozás is, ami javítja a lakosság életkörülményeit.
A demencia gyakorisága egyre jobban növekszik az alacsony és közepes jövedelmű országokban, mint a magas jövedelmű országokban, az elöregedő népesség és a potenciálisan módosítható kockázati tényezők gyakoribb előfordulása miatt. A prevenciót célzó intervenciók eredményezhetik a legnagyobb arányban a demencia csökkenését az alacsony és közepes jövedelmű országokban.

\section{AJÁNLÁSOK A DEMENCIA MEGELŐZÉSÉRE}

Fektessünk nagyobb hangsúlyt a megelőzésre! A megelőzés mind népegészségügyi, mind szakpolitikai beavatkozásokat igényel. A demencia kialakulását egyénre szabott beavatkozásokkal és népegészségügyi programokkal megelőzhetjük, melyek már a korai életkorban elkezdődnek és egész életen át tartanak. A szakpolitikai intézkedéseknek meg kell határozniuk a magas kockázati csoportokat a megfelelő beavatkozások érdekében.

Valósítsunk meg konkrét, egész életen át tartó beavatkozások a demencia kockázati tényezőinek csökkentérésre!

Törekedjünk arra, hogy 40 éves kor után a szisztolés vérnyomás ne haladja meg a $130 \mathrm{Hgmm}$-t!

Halláskárosodás esetén ösztönözzük a hallókészülék viselését, magas zajterhelés esetén törekedjünk a halláskárosodás megelőzésére!

Csökkentsük a dohányfüst-ártalmat és a légszennyezettségnek való kitettséget!

Előzzük meg a fejésérüléseket!

Korlátozzuk az alkoholfogyasztás heti legfeljebb 21 egységre!

Ne dohányozzunk! A dohányzásról való leszokás még későbbi életkorban is csökkenti a demencia kockázatát.

Minden gyermek részesüljön legalább középiskolai szintű oktatásban!

Törekedjünk az egészséges testsúly megtartására és a cukorbetegség megelőzésére!

Legyünk fizikailag aktívak minden életkorban!

A demencia egyéb feltételezett kockázati tényezőinek - pl. az alvásminőség - javításával 
hozzájárulhatunk általános egészségi állapotunk megőrzéséhez.

\section{AJÁNLÁSOK DEMENCIÁBAN SZENVEDŐK SZÁMÁRA}

Nyújtsanak átfogó, holisztikus ellátás a diagnózist követően! A demenciával diagnosztizált személyek gondozása során kiemelt figyelmet kell fordítani a betegek testi és lelki egészségére, szociális ellátására és támogatására. A demenciában szenvedő egyének már meglévő alapbetegségeinek megfelelő gondozásával, egész- ségük karban tartásával megelőzhetőek a kórházi kezelések.

Kezeljék a neuropszichiátriai tüneteket! A specifikus, többkomponensű beavatkozásokkal csökkentik a demenciában szenvedő betegek neuropszichiátriai tüneteit. A pszichotróp gyógyszerek gyakran hatástalanok, valamint súlyos mellékhatásaik lehetnek.

Gondoskodjunk a családgondozókról! A családgondozók jóllétét szolgáló beavatkozások hoszszútávú hatással vannak a depresszióra és szorongásos tünetekre, javítják az életminőségüket, így megelőzhető a szakemberek kiégése. Mindez költséghatékonyságot és pénzmegtakarítást eredményez.

\section{TANULSÁGOK A HAZAI SZAKEMBEREK SZÁMÁRA}

Mint a fentiekben is láthattuk a demencia prevenciója, gondozása és a hozzá kapcsolódó intervenciók komplexek, átszövik az élet szinte minden területét. A Bizottság által azonosított három új megelőzhető kockázati tényező: traumás fejsérülések, túlzott alkoholfogyasztás és légszennyezettség voltak. A traumás fejsérülések megelőzése érdekében hasznos lehet, ha például a mindennapos testnevelés órákon ás sportfoglalkozásokon a labdajátékok során óvni szükséges a gyerekek fejét az iskolában. Hazánkban az egy főre jutó alkoholfogyasztás közel egy literrel több, mint az európai átlag, ennek visszaszorítása komplex népegészségügyi beavatkozást és interszektoriális együttműködést igényel. A légszennyezettség csökkentése elsődlegesen nem az egészségügyi szektor feladata, bár a légszennyezettség népegészségügyi hatásai jelentősek. Ez utóbbi szintén elképzelhetetlen interszektoriális együttmüködés nélkül. 